\title{
A Study on Coordinating the Relationship Between Human Development and Social Development from the Perspective of "Real man"
}

\author{
Yuanyuan Kong ${ }^{1 *}$ \\ ${ }^{1}$ Enter Author Affiliation: School of Marxism, Beijing Jiaotong University, Beijing, 100044, China \\ *Corresponding author: Yuanyuan Kong. Email: 1609375700@qq.com
}

\begin{abstract}
"Real man" and related theories are Marx's important thesis on human and social development. It closely links human development and social development through historical practices. At the same time, "real man" have its inherent stipulations: practice, history, and openness, which makes certain requirements for human development and social development, and provides material power, sustainable method and innovative ideas for coordinating the relationship between human development and social development.
\end{abstract}

Keywords: Real man, Human development, Social development

\section{PRACTICE: THE IMPETUS TO COORDINATE THE RELATIONSHIP BETWEEN HUMAN DEVELOPMENT AND SOCIAL DEVELOPMENT}

Marx and Engels pointed out that "material living conditions are not only the prerequisite and basis for the survival and development of Real man, but also the result of their practical activities." [1] Here, Marx and Engels emphasized that the existence of "Real man" [2] is a real existence, and the focus lies in the meaning of the material production practice they are engaged in, rather than pure spiritual existence or animal natural existence. "Real man" have inherent regulations. Analyzing the problem of coordination between human development and social development from the perspective of "Real man", it is from its inherent stipulation that highlights the special and superiority of the relationship between human development and social development.

\subsection{Human practice}

Production practice distinguishes humans from animals [1]. "Perceptual activity", that is, practice, is the primary internal requirement of "Real man". When Marx criticized Feuerbach, he pointed out that human social history can only be the unfolding process of "perceptual activities" of "Real man". The actual material production practice has enabled human beings to obtain the particularity of being human. From then on, history began to transition from natural history to human history. Production labor has become the essential difference between humans and animals. As the subject of practice, people obtain the material materials needed for survival and development from practical activities. At the same time, they are also transforming their spiritual world in the process of practice. People's cognition of nature and society becomes more complicated as practice becomes more complicated. profound. Based on the unity of subject and object in the practical process [3], human practice not only provides material power for self-development and social development, but also spiritual power, which is even more prominent under special conditions. On the other hand, from a conceptual point of view, human practice is more individualistic than social practice, and therefore more creative. Human practice is not only the material power of human development and social development, but also the spiritual power.

\subsection{Social practice}

"Real man" create human society through practical activities. Material production activities, as the basic form of practice, determine political activities, cultural activities and all other activities. In the course of practice, the understanding and transformation relationship between man and society is further deepened, so as to provide material conditions for man's 
development and social development to meet their needs. When the division of labor is formed, social relations become more complicated. Outside of a single production relationship, communication relations become a bridge between human development and social development. Thereby, a dynamic social scene is presented in the interweaving relationship between man and man, man and society, and man and nature. The practice of "Real man" not only accelerates the production and reproduction of means of living, but also accelerates the production and reproduction of social relations. As a result, the actual human practice becomes the material power that coordinates the relationship between human development and social development, meets the actual needs of human development, and also provides the necessary material conditions for social development, while putting human development and social development in practice Unity, social development creates conditions for human development, human development provides a source of power for social development, and the two promote each other.

\subsection{Practice to meet needs}

"Real man" meet their own needs through practical activities and transform themselves in practice. "Real man" need continuous satisfaction of personal needs to realize themselves, and the path is practice. People meet their needs through realistic perceptual activities, that is, the practice of material production. When the needs are met, the individuals will have new needs. In this way, it is through practice that real people are constantly confirming and developing themselves through the process of "needs-needs to be met-new needs-new needs to be met"[4]. Social needs and human needs have something in common, but they cannot simply be equivalent to human needs. Specifically speaking, social needs are the organic sum of individual needs and restrict the satisfaction of individual needs. Human needs and practical activities to meet needs are social. From a practical perspective, social development also revolves around the process of "needs-needs to be metnew needs-new needs to be met". The satisfaction of needs and the creation of new needs occupy an important position in the process of coordinating human development and social development. As a result, human development and social development gain unity in the practice of meeting needs.

\section{HISTORY: A SUSTAINABLE METHOD TO COORDINATE THE RELATIONSHIP BETWEEN HUMAN DEVELOPMENT AND SOCIAL DEVELOPMENT}

History is another dimension of "Real man" [5], and it is also an indispensable perspective for development. It can be said that starting from history can improve the breadth and depth of development. Analyzing the issue of coordinating the relationship between human development and social development from a historical perspective can incorporate time and space considerations vertically and horizontally, expand possibilities for development, and better respond to challenges.

\subsection{Historical continuity of development}

The prerequisite for the existence and development of "Real man" is human material production activities. In such a social material activity, "Real man" can generate and continuously improve themselves. This gradual development process embodies "Real man". The history of people. Marx pointed out that people in reality have historical stages, and ignoring this point is tantamount to "morally hypocritical and deceptive quack talk" [1]. Without "Real man", history cannot be talked about; without history, "Real man" cannot explain its generation process. "As a regular premise of human history, man is also a regular product and result of human history, and man only becomes a prerequisite if he is his own product and result."[6]Human development and social development are carried out in the historical field, and at the same time promote the progress of history. Human development and social development can only be further coordinated from internal factors if the prerequisite and ultimate goal of development is to align with "Real man". The relationship between the two. The history of development is as important as the development of history.

\subsection{Historical stages of development}

Therefore, the analysis of human development and social development should place human and society in history, in the relationship between human and history, society and history, and the three. In other words, no matter how people and society develop, they are inseparable from the accumulation of historical experience. Under specific historical conditions, people's material and time activities are limited, and human development and social development are actually gradually getting rid of historical experience. Passive and affected state under established conditions, and produce and communicate according to their own needs. The key to this question is to provide a historical perspective for the sustainability of human development and social development. Human development and social development are each part of historical progress. At the same time, human development and social development are generated, accumulated, and continued in the long river of history... The sustainability of human development and social development is regulated here and it shows that this kind of sustainability is a concentrated reflection of the historical dimension of 
"Real man", and it is also the responsibility of human development and social development to free nature.

\subsection{Historical sustainable development}

Historical development has both continuity and stage, which is fundamentally due to the unbalanced development of productivity. "Each stage of history has encountered certain material results, a certain amount of total productivity... so that it has a certain development and has special properties" [7] and then considers the limitations of human cognition and the external environment. Factors have caused historical development to show a fluctuating trend and will also encounter development barriers. Each stage of historical development has the characteristics of each stage, and the progress and comparison of the previous stage and the limitations of future development coexist. Thereby, Human beings are historical people, society is historical society, and development is historical development. They also put forward higher requirements for sustainability. The meaning of sustainability lies in the dynamic balance of human development and social development. Each stage of development should not be temporary and one-off, but orderly and sustainable. To expand the sustainability of human development and social development, we must adhere to the combination of history and logic to promote the further deepening of the combination of theory and practice, reflect the inherent inevitability of human development and social development in general, and follow the historical laws of the development process Sex, insisting on the historical and logical unity of human development and social development.

\section{OPENNESS: INNOVATIVE THINKING FOR COORDINATING THE RELATIONSHIP BETWEEN HUMAN DEVELOPMENT AND SOCIAL DEVELOPMENT}

The openness of "Real man" is closely related to their essence and self-awareness. The relationship between man and himself, between man and man and society is the proper meaning in dealing with the relationship between human development and social development.

\subsection{Openness based on human nature}

From its essence, "the person as a whole is a 'Real man'." [8] The essence of a realistic person is the sum of all social relations, and social relations are constantly evolving and changing, therefore, "real persons" Its essence is not rigid, it is still being formed. It can be seen from this that "Real man" have a future, and their future is unlimited and open. It is almost impossible to start from a fixed, temporary, and a certain segment of people and then introduce the development path of people and society. The conditions of human development and social development are not static. The stability of the stage will change with changes in social practice activities. Therefore, theoretically, the space for human development and social development is unpredictable. Moreover, human development and social development include the actual connection between people, between people and nature, and between people and society. More importantly, it confirms the generation of this connection, so "Real man" have gained constant with the possibility of development, people and society obtain innovative ideas for sustainable development.

\subsection{Openness based on self-awareness}

From the perspective of self-awareness, "Real man" are a kind of people who have been gradually added with historical and empirical marks in society, which is a prerequisite for the beginning and development of social history. In the practical activities of "Real man", the relationship between people and the external social environment is not only the relationship between transformation and being transformed, but also the relationship between understanding and being recognized, which is fundamentally different from animal behavior, and its purpose is to meet the needs of human survival and development. The difference between humans and animals is that they have the ability to learn, reform and feedback. They are also transforming themselves while creating the objective world. They are not a closed circle, but a spiral development form. Therefore, the internal regulation of the self-consciousness of "Real man" makes human development and social development obtain "realistic openness". It is worth noting that opening is not only reflected in the horizontal opening of a single thing, but also in the vertical opening of the entire era. Its vertical opening lies in the huge potential contained in the society itself.

\subsection{Open and innovative thinking}

Human development and social development have consistency, but this consistency is not the sameness that loses individuality. When analyzing the relationship between human development and social development, one should be open, maintain diversity, give full play to the role of personal consciousness, use subjective initiative to actively achieve self-development, encourage outstanding individuals to make outstanding contributions and lead the trend of social development. Corresponding societies should increase tolerance, diversify and integrate, and gather more forces for social development. "Real man" open up opportunities for innovative development paths for human development and social development from an internally open 
dimension. Openness is the prerequisite of innovation, and innovation is the requirement of openness. It can be said that open development is the inherent requirement of the subject's personality [9]. This process is to break through the objective and subjective obstacles in the process of human development and social development, and make the practical and historical process smoother and go further.

"Real man" is an important concept in Marxist theory. Marx elaborated on the internal regulations of man and society through the "real man", which contains his insights into the relationship between human development and social development. In a word, in the process of the inherent regulation of "Real man" from potential to reality, human development and social development have gradually changed from single to rich, from one-sided to comprehensive, from deformity to perfection, and vice versa. Human development and social development are conditions for each other in the relationship between subject and object. In practice, they are subject to each other, unified in history, and innovation in opening up. The internal regulations of "Real man" enlighten people to actively practice, coordinate their personal internal needs and social internal needs; keep up with the times, grasp the direction of personal development and the trend of the times; open up thinking, realize personal innovative development and openness Sexual development, in order to find the right position of the individual in coordinating the relationship between human development and social development.

\section{CONCLUSION}

Based on the study of the Marxist theory of human all-round development," Real man" and its inherent stipulations provide an operational analysis dimension for coordinating the relationship between human development and social development. From the dimension of practice, it is both the path and content of human development and social development. Its fundamental lies in the satisfaction of human needs by practice. Human development and social development are unified in the satisfaction of practice and needs. From the dimension of history, human development and social development have the characteristics of continuity and stage. According to this, the sustainable development in line with the combination of history and logic enables human development and social development to reach a dynamic balance. From the dimension of openness, it has endogenous significance for the realization of human nature and the establishment of self-awareness, and it provides the possibility for innovative human development and social development ideas. Basically along the line of the subject impetus, method, and thinking, it provides a characteristic theoretical analysis for coordinating the relationship between human development and social development.

\section{AUTHORS' CONTRIBUTIONS}

The conception, design, translation and modification of this article are all completed by myself.

\section{ACKNOWLEDGMENTS}

Thanks are due to Ms.Xu for suggestions for topic selection and to Mr.Peng for valuable discussion. I am grateful to the scholars of related research, especially those in the references, whose theoretical research has given me a lot of inspiration.

\section{REFERENCES}

[1] Marx and Engels. German ideology [M]. In "Selected Works of Marx and Engels (Volume One)", Beijing: People's Publishing House 2012(3):141-215.

[2] Zhao Huafei. Marx's concept of "Real man" [D]. Central Party School of the Communist Party of China. 2018.

[3] Ma Xiufen.On the unity of subjective and objective and its significance[J].Journal of Northeast Normal University,1984(01):33-37.

[4] Marx, Engels. Collected Works of Marx and Engels (Volume1)[M]. Beijing: People's Publishing House, 2009.532.

[5] Wan Adong, Chen Shufang. Marxist thoughts on human nature[J]. Journal of the Party School of Nanchang Municipal Committee of the Communist Party of China,2019,17(05):2-5.

[6] Marx and Engels. Capital [M]. In "Selected Works of Marx and Engels (Volume IV)", Beijing: People's Publishing House, 2012(3): 36-50.

[7] Marx, Engels. The Complete Works of Marx and Engels:(Volume1) [M]. Beijing: People's Publishing House, 1960.43.

[8] Lu Siyu. Marx's "realistic man" transcends abstract man[D]. Heilongjiang University. 2018.

[9] He Shan Kan. The Value Orientation and Perplexity in the Transformation of Social Subjects in Contemporary China[J]. Journal of East China University of Science and Technology (Social Science Edition),2002(03):21-27. 